\title{
Analiza warunków pracy złoża ropy naftowej Potok na podstawie wybranego okresu eksploatacji
}

\author{
Albin Wojnar, Czesław Rybicki (D) \\ AGH Akademia Górniczo-Hutnicza, Wydział Wiertnictwa, Nafty i Gazu, Kraków
}

\begin{abstract}
Streszczenie: Złoże Potok będące przedmiotem analizy położone jest w południowo-wschodniej części Polski. Główną formacją geologiczną jest II piaskowiec ciężkowicki. Oszacowane pierwotne zasoby geologiczne ropy naftowej złoża Potok wynoszą 2648,94 tys. t, zasoby gazu ziemnego towarzyszącego ropie wynoszą $818,74 \mathrm{mln} \mathrm{Nm}^{3}$. Rejestrowane niekompletne dane pochodzące z eksploatacji zachowały się od roku 1945. Celem autorów była analiza warunków eksploatacji złoża Potok, ilości wydobytej ropy naftowej, gazu ziemnego i wody. W artykule przeanalizowano przebieg eksploatacji ropy oraz wody dla trzech bloków II piaskowca ciężkowickiego od 1945 do 2013 roku. Z przeprowadzonej analizy wynika, że bloki wschodni i środkowy są bardzo silnie zawodnione. Sugestia o zawodnieniu bloków wynika z ilości wody dopływającej do odwiertów. Możliwe jest istnienie języków wodnych lub stożków wodnych. W ocenie autorów eksploatacja ropy naftowej na blokach wschodnim i środkowym jest możliwa przez 5-6 lat, a na bloku zachodnim może trwać jeszcze przez co najmniej 10 lat. Kres tej eksploatacji może być podyktowany wyłącznie względami ekonomicznymi. Autorzy w chwili obecnej prowadzą prace nad próbą uproszczonego opisu matematycznego procesu eksploatacji ropy naftowej, gazu ziemnego i wody z bloku zachodniego złoża Potok.
\end{abstract}

Słowa kluczowe: piaskowiec ciężkowicki, ropa, woda, gaz

\section{ANALYSIS OF THE OPERATING CONDITIONS OF THE POTOK OIL FIELD ON THE BASIS OF THE SELECTED PRODUCTION PERIOD}

\begin{abstract}
The Potok field under study is located in the south-eastern part of Poland. The main geological formation is the II Ciężkowice sandstone estimated primary crude oil resources of the Potok field are 2,648.94 thousand tonnes, and resources of natural gas associated with crude oil at the level of 818.74 million $\mathrm{Nm}^{3}$. Registered incomplete mining data has been preserved since 1945 . The aim of the authors was to analyze the operating conditions of the Potok reservoir, the amount of crude oil, natural gas and water extracted. The article analyzes the course of oil and water extraction for three blocks of the 2nd Ciężkowice sandstone from 1945 to 2013. The analysis shows that the eastern and middle blocks are strongly waterlogged. The suggestion of block failure is due to the amount of water flowing into the wells. The existence of water tongues or water cones is possible. In the opinion of the authors, the production of crude oil in the eastern and middle blocks is possible for a period of 5-6 years, in the western block it may continue for at least 10 years. The end of this exploitation may only be dictated by economic considerations. The authors are currently working on an attempt at a simplified mathematical description of the process of exploitation of crude oil, natural gas and water from the western block of the Potok field.
\end{abstract}

Keywords: Ciężkowice sandstone, oil, water, gas

https://doi.org/10.7494/978-83-66727-48-9_13 


\section{Wprowadzenie}

Złoże ropy Potok położone jest w środkowej części antykliny Potoka, stanowiącej jeden z elementów fałdowych jednostki śląskiej Karpat fliszowych (Wdowiarz 1960, Biuletyn 1968, Karkowski 1993).

Eksploatację ropy naftowej na obszarze złoża Potok prowadzono od końca XIX wieku (1890 rok). Ogółem w latach 1890-1998 na obszarze złoża odwiercono 237 otworów. Sumaryczne wydobycie płynów ze złoża Potok od początku eksploatacji do końca 2013 roku wyniosło: 841,66 tys. t ropy naftowej, 262,28 $\mathrm{mln} \mathrm{Nm}^{3}$ gazu ziemnego i około 616 tys. $t$ wody złożowej (Dokumentacja 2010).

\section{Krótka charakterystyka położenia geograficznego złoża ropy naftowej Potok}

Geograficznie obszar złoża ropy naftowej Potok należy do Pogórza Środkowobeskidzkiego. Powierzchnia terenu jest dość zróżnicowana i można ją zaliczyć do terenów podgórskich. Ukształtowana jest w postaci niewielkich zboczy i grzbietów o przebiegu prawie poprzecznym do osi podłużnej złoża. Wysokość nad poziomem morza zawiera się w granicach od 260 m n.p.m. do 325 m n.p.m. Większą część obszaru górniczego stanowią tereny rolne, przeważnie nieużytki i łąki. Obszar złoża pokrywa lokalna sieć dróg asfaltowych i żwirowych. Wzdłuż głównej drogi Krosno - Jasło, która przebiega na południe od złoża Potok (w zachodniej części go przecina), oraz przy drogach lokalnych teren jest zabudowany. Złoże ropy naftowej Potok położone jest w województwie podkarpackim, w powiecie krośnieńskim, w gminie Jedlicze, w miejscowości Potok.

\section{Elementy budowy geologicznej złoża Potok}

Złoże ropy naftowej Potok występuje w jednostce śląskiej centralnej depresji Karpat fliszowych we wschodniej części mniejszej jednostki tektonicznej - antykliny Potoka (Dokumentacja 2010). Facja śląska Karpat fliszowych obejmuje największy obszar. Ciągnie się od granicy wschodniej aż po Dunajec na szerokości $30 \mathrm{~km}$. W kierunku zachodnim jednostka zwęża się - od południa przykryta jest przez płaszczowinę magurską, a od północy dochodzi do brzegu Karpat. Charakterystyczną cechą jednostki śląskiej jest pełny rozwój utworów fliszu od dolnej kredy do oligocenu. Kredę dolną reprezentują łupki i wapienie cieszyńskie oraz piaskowce. W obrębie tej serii wydzielone zostały warstwy: grodziskie, wierzowskie, lgockie i godulskie. Kredę górną reprezentują warstwy istebniańskie. Duże znaczenie mają utwory wieku paleocen-eocen. Należą do nich piaskowce ciężkowickie, będące najbogatszym zbiornikiem w Karpatach. 
Oligocen reprezentują łupki menilitowe z piaskowcami kliwskimi, a także warstwy krośnieńskie. Cały fałd Potoka, którego elementem jest złoże Potok, rozciąga się od przełomu rzeki Sanoczek na wschodzie po Roztoki i Jasło na zachodzie, gdzie jest gwałtownie zrzucony na wielkiej poprzecznej dyslokacji Jasła. Na wschodzie, na powierzchni uwidacznia się jako wąska wychodnia dolnych warstw krośnieńskich, rozszerzająca się w kierunku miejscowości Jaćmierz. Od tej miejscowości aż do Trześniowa przykryty jest utworami czwartorzędowymi terasu rzeki Wisłok. W Trześniowie na powierzchni uwidacznia się wychodnią pstrego eocenu i łupków menilitowych, skąd w kierunku zachodnim na kilku dyslokacjach poprzecznych zanurza się i całkowicie zanika na terasie rzeki Morawa. Dalej, w kierunku zachodnim fałd Potoka zaczyna się podnosić na licznych dyslokacjach poprzecznych; w rejonie miejscowości Krosno-Potok odsłania w swoim jądrze pstre łupki z piaskowcami ciężkowickimi. Kulminację uzyskuje w rejonie Turaszówki, gdzie w jądrze odsłania II piaskowiec ciężkowicki. Począwszy od miejscowości Potok w kierunku zachodnim aż do Jasła, na kolejnych licznych dyslokacjach poprzecznych znowu się zanurza. Fałd Potoka o długości całkowitej ponad $40 \mathrm{~km}$ w strefie wgłębnej ma charakter antykliny prostej, o nachyleniu skrzydeł na zewnątrz struktury z dwoma podłużnymi pęknięciami śródfałdzia, rozdzielającymi ją na trzy elementy: główny - środkowy oraz dwa skrajne - północny i południowy.

W budowie geologicznej fałdu biorą udział następujące poziomy stratygraficzne:

- warstwy istebniańskie, wykształcone w facji piaskowcowo-łupkowej,

- łupki pstre z dwoma poziomami piaskowców ciężkowickich (eocen),

- seria menilitowa z piaskowcami typu kliwskiego (oligocen),

- warstwy krośnieńskie rozpoziomowane na dolne o charakterze piaskowcowym, środkowe piaskowcowo-łupkowe i górne o charakterze łupkowym (oligocen).

\subsection{Elementy stratygrafii złoża Potok}

W budowie geologicznej w rejonie złoża ropy naftowej Potok pokazanej na rysunku 1 występują następujące poziomy. Są to:

- warstwy krośnieńskie (oligocen),

- łupki menilitowe z rogowcami (oligocen),

- I pstre łupki (eocen),

- I piaskowiec ciężkowicki (eocen),

- II pstre łupki (eocen),

- II piaskowiec ciężkowicki (eocen),

- III pstre łupki (eocen),

- górne warstwy istebniańskie (czarnorzeckie) (paleocen),

- górne warstwy istebniańskie (czarnorzeckie) (górna kreda). 

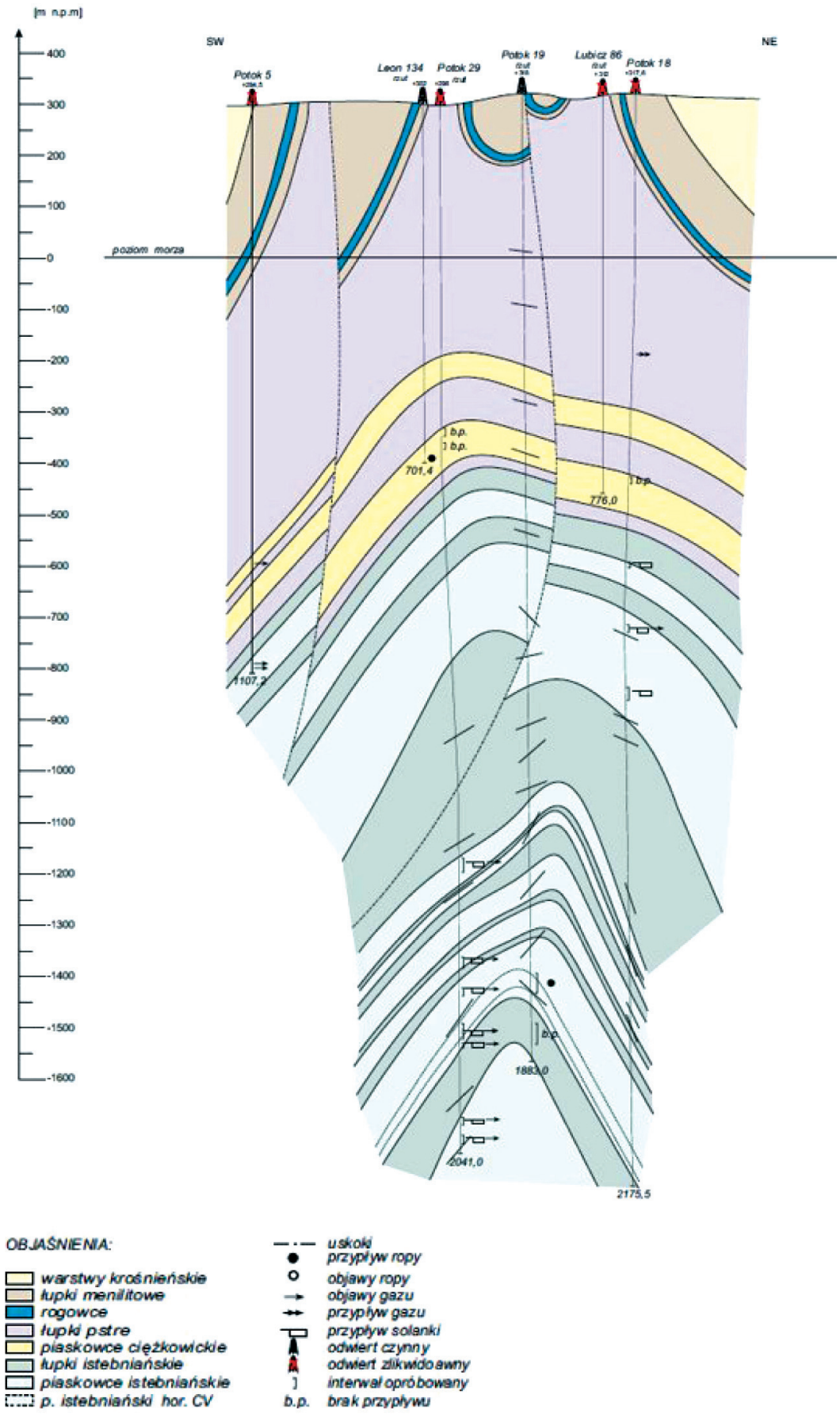

Rys. 1. Przekrój geologiczny złoża ropy naftowej Potok Źródło: Dokumentacja (2010) 
Wszystkie ogniwa litostratygraficzne nawiercone były odwiertami w rejonie złoża Potok. Skałami zbiornikowymi dla złoża ropy naftowej Potok są: II piaskowiec ciężkowicki (eocen) i piaskowce warstw istebniańskich. Piaskowiec ciężkowicki wykształcony jest w postaci kompleksów piaskowcowo-łupkowych. Składają się na nie pakiety gruboławicowych piaskowców przewarstwione seriami szarozielonych i czerwonych łupków. Piaskowce są szare i jasnoszare, przeważnie średnio- i gruboziarniste, a nawet zlepieńcowate, o lepiszczu ilastym; podrzędnie występują piaskowce drobnoziarniste. Miąższość II piaskowca ciężkowickiego w rejonie złoża Potok zmienia się w granicach 50-85 m.

\subsection{Budowa tektoniczna złoża ropy naftowej Potok}

Budowa przestrzenna antykliny Potoka na odcinku występowania złoża ropy naftowej i gazu ziemnego Potok jest podobna jak w innych rejonach $\mathrm{z}$ obszaru podkarpacia, w których występują akumulacje węglowodorów. Tektonikę fałdu kształtują liczne dyslokacje podłużne i poprzeczne, nadając występującym w jego obrębie złożom węglowodorów charakter blokowy. Część dyslokacji została stwierdzona na powierzchni, a część występuje jedynie w głębszych partiach fałdu. W kierunku powierzchni większość dyslokacji ulega wygaszeniu. Poszczególne bloki złoża oraz horyzonty mają zróżnicowane: głębokość zalegania, miąższość horyzontu roponośnego, nasycenie węglowodorami czy aktywność wód złożowych.

W obrębie złoża Potok stwierdzono występowanie pięciu uskoków poprzecznych oddzielających złoże od złóż sąsiednich i dzielących go na trzy bloki pokazane na rysunku 2:

- blok wschodni,

- blok środkowy,

- blok zachodni.

Głównym horyzontem eksploatacyjnym na złożu Potok jest II piaskowiec ciężkowicki. Na bloku wschodnim II piaskowiec ciężkowicki zalega najpłycej, bo na głębokości $260 \mathrm{~m}$ od powierzchni, przy wschodniej dyslokacji w kierunku zachodnim oś antykliny lekko się zapada i przy zachodniej dyslokacji piaskowiec zalega na głębokości $700 \mathrm{~m}$ od powierzchni.

W kierunku zachodnim występuje blok środkowy, który jest najmniejszym elementem tektonicznym złoża Potok. Na bloku tym stwierdzono występowanie dwóch dyslokacji podłużnych, które oddzielają element główny - środkowy, jedyny produktywny - od północnego i południowego, bez przemysłowej akumulacji węglowodorów.

Dyslokacja na południowym skrzydle antykliny widoczna jest na powierzchni terenu, przebiega w znacznej odległości od osi antykliny, daleko poza strefą akumulacji ropy naftowej w rejonie silnego pochylenia jej skrzydła. Na skrzydle północnym uskok podłużny nie został stwierdzony na powierzchni. 

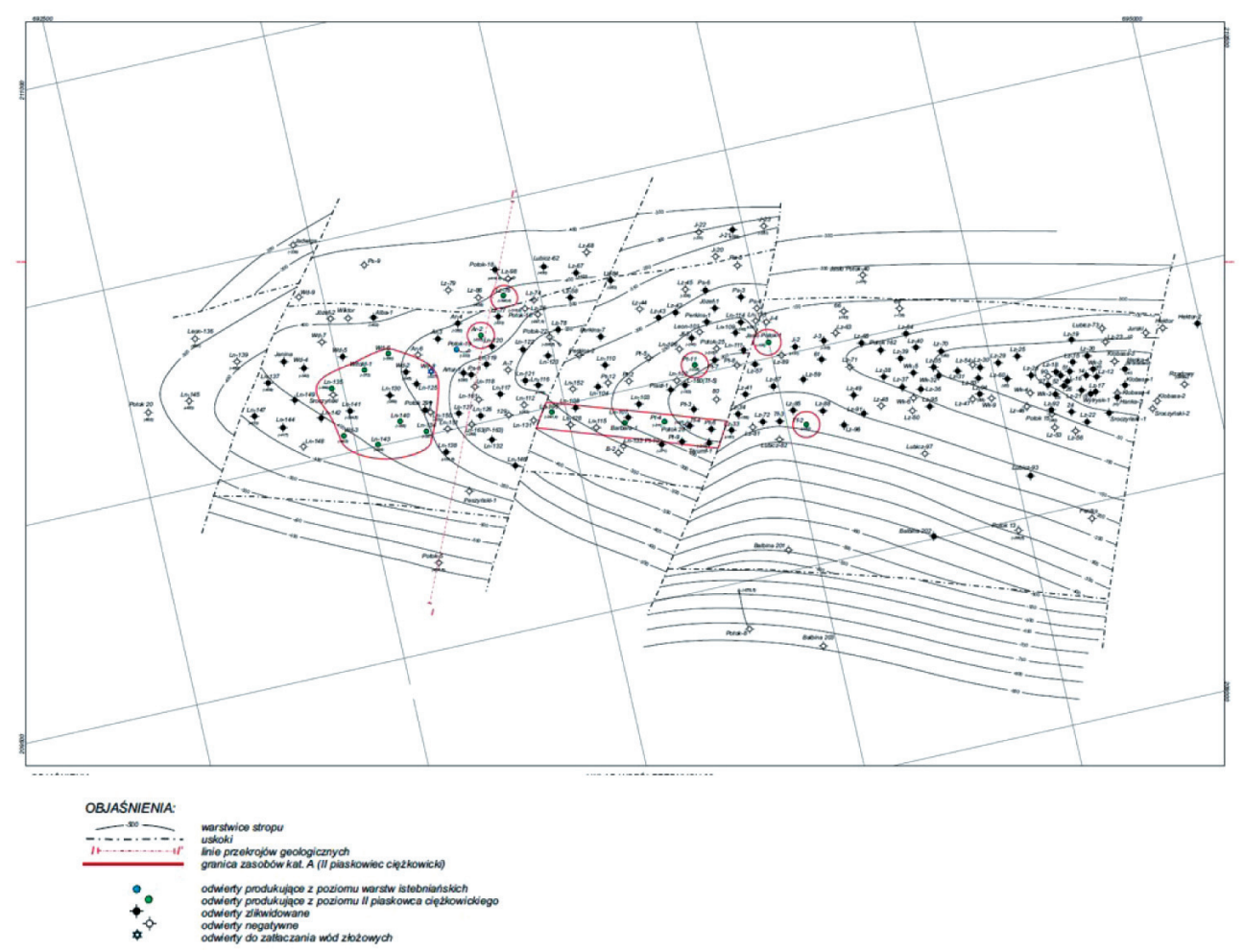

Rys. 2. Mapa strukturalna II piaskowca ciężkowickiego złoża ropy naftowej Potok Źródło: Dokumentacja (2010)

W bloku środkowym II piaskowca ciężkowickiego główny element złożowy oddziela się od nieproduktywnego bloku północnego. Warstwy te zalegają płycej we wschodniej części bloku, bo na głębokości około $470 \mathrm{~m}$ od powierzchni, a z uwagi na pochylenie osi fałdu w kierunku zachodnim zalegają na głębokości około $580 \mathrm{~m}$ od powierzchni.

W bloku zachodnim, najbardziej zasobnym i najmniej zawodnionym, utwory II piaskowca ciężkowickiego w części wschodniej zalegają na głębokości około $540 \mathrm{~m}$ od powierzchni, zaś w części zachodniej na głębokości około $700 \mathrm{~m}$ od powierzchni.

Analizując przebieg stropu II piaskowca ciężkowickiego na mapie strukturalnej, a także na przekrojach geologicznych, można zauważyć, że antyklina w rejonie złoża Potok najbardziej wyniesiona jest na bloku wschodnim, zaś w kierunku zachodnim na dyslokacjach poprzecznych obniża się i najgłębiej zalega na bloku zachodnim.

Wgłębna budowa antykliny Potoka w rejonie dokumentowanego złoża jest słabo rozpoznana. Najlepiej rozpoznana jest na bloku zachodnim w wyniku stwierdzonej, na podstawie prac poszukiwawczych oraz rozpoznawczych, akumulacji ropy naftowej w dolnych warstwach istebniańskich. 


\section{Historia rozpoznania i obecny stan złoża ropy naftowej Potok}

Złoże ropy naftowej Potok odkryte zostało w 1890 roku szybem kopanym o głębokości około 20 m, z którego uzyskano przypływ gazu. Szyb zlokalizowany był na granicy ze złożem Turaszówka. Pierwszym odwierconym otworem był otwór Lubicz 12 (1891 rok), z którego uzyskano przypływ ropy naftowej z głębokości około $240 \mathrm{~m}$. Do roku 1910 wykonane zostały 143 odwierty w zakresie głębokościowym 280-780 m, w znacznej większości produktywne. Do połowy lat 60 . XX wieku wykonano w sumie 226 odwiertów. W latach 1969-1994 wykonano osiem otworów poszukiwawczych, w latach 1997-1998 wykonano dwa otwory rozpoznawcze.

Na podstawie dokumentacji geologicznej złoża (Wdowiarz 1960, Dokumentacja 2010) autorzy zestawili liczbę wykonywanych otworów w złożu Potok w poszczególnych latach:

- 1890-1900 - wykonano 109 otworów,

- 1901-1910 - wykonano 34 otwory,

- 1911-1920 - wykonano 18 otworów,

- 1921-1930 - wykonano 32 otwory,

- 1931-1940 - wykonano 19 otworów,

- 1941-1950 - wykonano 11 otworów,

- 1951-1960 - wykonano 3 otwory,

- 1961-1970 - wykonano 3 otwory poszukiwawcze,

- 1971-1980 - wykonano 3 otwory poszukiwawcze,

- 1981-1990 - wykonano 3 otwory poszukiwawcze,

- 1991-2000 - wykonano 2 otwory rozpoznawcze.

Ogółem na obszarze złoża ropy naftowej Potok i w bliskim jego sąsiedztwie wykonano 237 otworów o łącznym metrażu około 139,3 tys. m (Wdowiarz 1960, Dokumentacja 2010). Na koniec 2009 roku pozostało w eksploatacji 17 odwiertów (w tym jeden służący do zatłaczania wód złożowych).

\section{Charakterystyka płynów złożowych wydobywanych ze złoża Potok}

Własności ropy naftowej eksploatowanej ze złoża Potok są zmienne i zależą od horyzontu, z którego ona pochodzi. Ropa naftowa eksploatowana z II piaskowca ciężkowickiego jest bezparafinowa, lekka, o gęstości w temperaturze $20^{\circ} \mathrm{C}$ w granicach: $815-839 \mathrm{~kg} / \mathrm{m}^{3}$ (średnio $824 \mathrm{~kg} / \mathrm{m}^{3}$ ). Lepkość ropy w temperaturze $20^{\circ} \mathrm{C}$ zmienia się 
w przedziale $1,14-1,30^{\circ} \mathrm{E}$. Ropa naftowa eksploatowana z warstw istebniańskich (odwiert Potok 19) jest ropą parafinową o zawartości parafiny 6,8-8,2\% i o gęstości w temperaturze $20^{\circ} \mathrm{C}$ w granicach $840-852 \mathrm{~kg} / \mathrm{m}^{3}$ ('́rednio $843 \mathrm{~kg} / \mathrm{m}^{3}$ ). Lepkość tej ropy w temperaturze $20^{\circ} \mathrm{C}$ zmienia się w przedziale $1,82-3,06^{\circ} \mathrm{E}$ - średnia lepkość wynosi $2,49^{\circ} \mathrm{E}$. Eksploatowany gaz od roku 1990 nie był raportowany i brak jest w dokumentacji złoża analizy jego składu.

Parametry złoża ropy naftowej i gazu ziemnego Potok zestawiono w tabeli 1 opracowanej na podstawie dokumentacji (Biuletyn 1968, Dokumentacja 2010).

Tabela 1

Zestawienie głównych parametrów złoża ropy naftowej i gazu ziemnego Potok

\begin{tabular}{|c|c|c|}
\hline Nazwa złoża & \multicolumn{2}{|c|}{ Potok } \\
\hline $\begin{array}{l}\text { Położenie złoża: } \\
\text { - miejscowość } \\
\text { - gmina } \\
\text { - powiat } \\
\text { - województwo }\end{array}$ & \multicolumn{2}{|c|}{$\begin{array}{c}\text { Potok } \\
\text { Jedlicze } \\
\text { krośnieński } \\
\text { podkarpackie }\end{array}$} \\
\hline Region & \multicolumn{2}{|c|}{ Karpaty fliszowe } \\
\hline Powierzchnia całkowita złoża [ha] & \multicolumn{2}{|c|}{76,24} \\
\hline Data rozpoczęcia eksploatacji & \multicolumn{2}{|c|}{$\begin{array}{c}\text { II piaskowiec ciężkowicki - } 1890 \text { r. } \\
\text { piaskowiec istebniański - październik } 1979 \text { r. }\end{array}$} \\
\hline Stratygrafia i litologia skały zbiornikowej & \multicolumn{2}{|c|}{$\begin{array}{c}\text { eocen, piaskowce ciężkowickie, górna kreda, } \\
\text { piaskowce istebniańskie }\end{array}$} \\
\hline Kopalina główna złoża & \multicolumn{2}{|c|}{ ropa naftowa } \\
\hline Rodzaj ropy naftowej & bezparafinowa & parafinowa \\
\hline Średnia gęstość ropy $t=20^{\circ} \mathrm{C}\left[\mathrm{kg} / \mathrm{m}^{3}\right]$ & 824 & 843 \\
\hline Parafina [\%] & nie oznaczono & 7,4 \\
\hline Siarkowodór [\%] & \multicolumn{2}{|c|}{ nie oznaczono } \\
\hline Rtęć [\%] & \multicolumn{2}{|c|}{ nie oznaczono } \\
\hline Kopaliny towarzyszące & \multicolumn{2}{|c|}{ woda i gaz ziemny w śladowych ilościach } \\
\hline Liczba poziomów ropo- i gazonośnych & \multicolumn{2}{|c|}{2} \\
\hline Głębokość udostępnienia złoża [m] & \multicolumn{2}{|c|}{$\begin{array}{l}\text { II piaskowiec ciężkowicki - 260-700 } \\
\text { piaskowce istebniańskie - 1712-1750 }\end{array}$} \\
\hline $\begin{array}{l}\text { Głębokość położenia wody } \\
\text { podścielającej }[\mathrm{m}]\end{array}$ & \multicolumn{2}{|c|}{$\begin{array}{l}\text { II piaskowiec ciężkowicki - nie określono } \\
\text { piaskowce istebniańskie - } 1432\end{array}$} \\
\hline Miąższość całkowita złoża [m] & \multicolumn{2}{|c|}{$\begin{array}{c}\text { II piaskowiec ciężkowicki } 50-85 \\
\text { piaskowce istebniańskie - 38, efektywna - 25,5 }\end{array}$} \\
\hline
\end{tabular}


Tabela $1 \mathrm{~cd}$.

\begin{tabular}{|c|c|}
\hline Porowatość średnia [\%] & $\begin{array}{l}\text { II piaskowiec ciężkowicki - 11,7-17,72 } \\
\text { piaskowce istebniańskie - } 13,0\end{array}$ \\
\hline Przepuszczalność [mD] & $\begin{array}{l}\text { II piaskowiec ciężkowicki - 2,92-298,88 } \\
\text { piaskowce istebniańskie - 0,7-20,5 }\end{array}$ \\
\hline Zapiaszczenie [\%] & $\begin{array}{c}\text { II piaskowiec ciężkowicki - nie określono } \\
\text { piaskowce istebniańskie - } 67,1\end{array}$ \\
\hline Współczynnik nasycenia [\%] & $\begin{array}{l}\text { II piaskowiec ciężkowicki - nie określono } \\
\text { piaskowce istebniańskie - } 89,50\end{array}$ \\
\hline Temperatura złoża $\left[{ }^{\circ} \mathrm{C}\right]$ & $\begin{array}{l}\text { II piaskowiec ciężkowicki - } 50 \\
\text { piaskowce istebniańskie - } 45\end{array}$ \\
\hline Ciśnienie denne pierwotne [MPa] & $\begin{array}{l}\text { II piaskowiec ciężkowicki - nie określono } \\
\text { piaskowce istebniańskie - } 22,85\end{array}$ \\
\hline $\begin{array}{l}\text { Ciśnienie głowicowe aktualne } \\
\text { s/przestrzeń [MPa] }\end{array}$ & $\begin{array}{l}\text { II piaskowiec ciężkowicki - } 0 / 0 \\
\text { piaskowce istebniańskie }-0 / 0.5\end{array}$ \\
\hline Wydajność [t/d] & początkowo $-13 \mathrm{t} / \mathrm{d}$, aktualnie $-0,03-1,0$ \\
\hline Wykładnik wodny [t/t] & 1,18 za 2009 r. \\
\hline Wykładnik gazowy $\left[\mathrm{nm}^{3} / \mathrm{t}\right]$ & $\sim 0,0$ \\
\hline Typ chemiczny wody złożowej & woda słona chlorkowo-kwaśno-węglanowa \\
\hline Stopień mineralizacji wody złożowej [g/l] & $\begin{array}{l}0,478-30,458 \\
\quad \text { śr. } 20,96\end{array}$ \\
\hline Warunki eksploatacji & grawitacyjne \\
\hline Współczynnik sczerpania & $0,33 / 0,30$ \\
\hline
\end{tabular}

Źródło: opracowanie własne na podstawie Biuletyn (1968), Dokumentacja (2010)

\section{Przebieg dotychczasowej eksploatacji złoża Potok na przykładzie II piaskowca ciężkowickiego}

Na podstawie danych liczbowych zamieszczonych w dokumentacji złoża i dostępnych dla autorów sporządzone zostały wykresy przebiegu wydobycia ropy naftowej i wody dla trzech bloków II piaskowca ciężkowickiego (głównego horyzontu złożowego), które były wspomniane wcześniej i pokazane na rysunku 2. Na rysunku 3 autorzy przedstawili wykres przebiegu eksploatacji ropy naftowej jako głównego płynu złożowego oraz wody w okresie od 1945 do 2013 roku dla bloku wschodniego II piaskowca ciężkowickiego.

$\mathrm{Na}$ rysunku 4 autorzy sporządzili wykres przebiegu eksploatacji ropy naftowej i wody z bloku środkowego II piaskowca ciężkowickiego. 


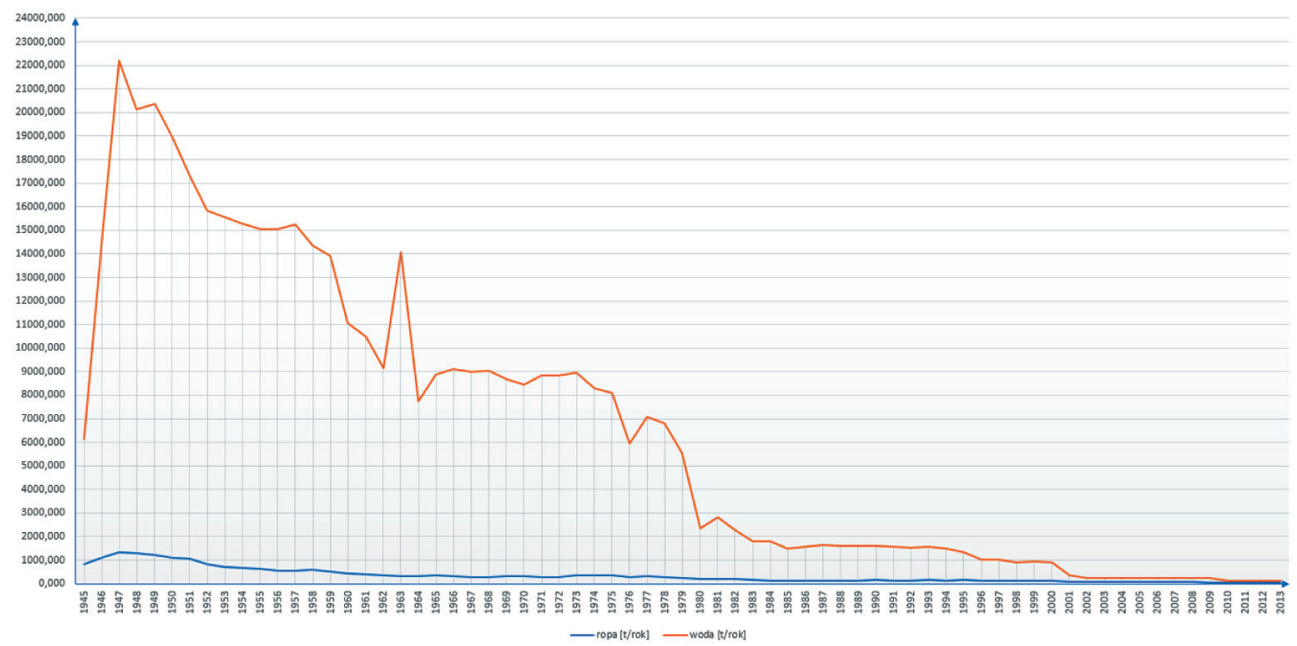

Rys. 3. Wykres przebiegu wydobycia ropy naftowej i wody ze złoża Potok

(II piaskowiec ciężkowicki - blok wschodni)

Źródło: opracowanie własne na podstawie Dokumentacja (2010)

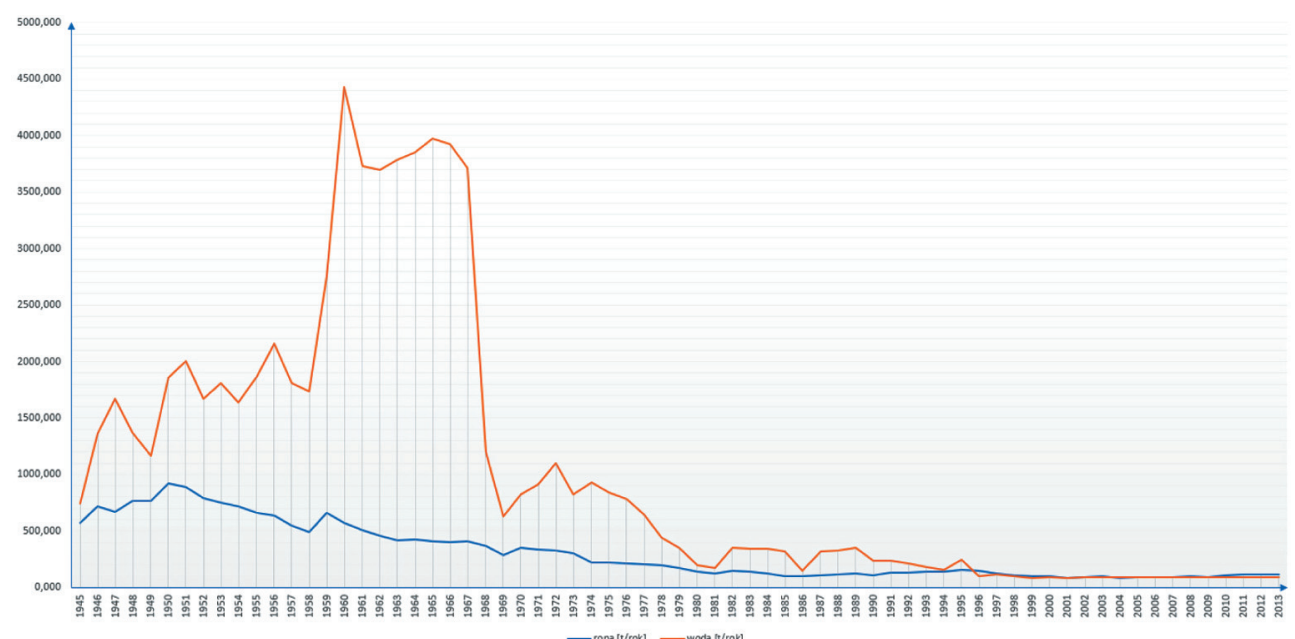

Rys. 4. Wykres przebiegu wydobycia ropy naftowej i wody ze złoża Potok

(II piaskowiec ciężkowicki - blok środkowy)

Źródło: opracowanie własne na podstawie Dokumentacja (2010)

Na rysunku 5 autorzy przedstawili wykresy przebiegu eksploatacji ropy naftowej i wody na bloku zachodnim II piaskowca ciężkowickiego.

Analizując zmiany wydobycia ropy naftowej i wody na rysunkach 3-5, można stwierdzić, że przebieg ich eksploatacji na poszczególnych blokach II piaskowca ciężkowickiego jest różny i powinien być osobno analizowany. 


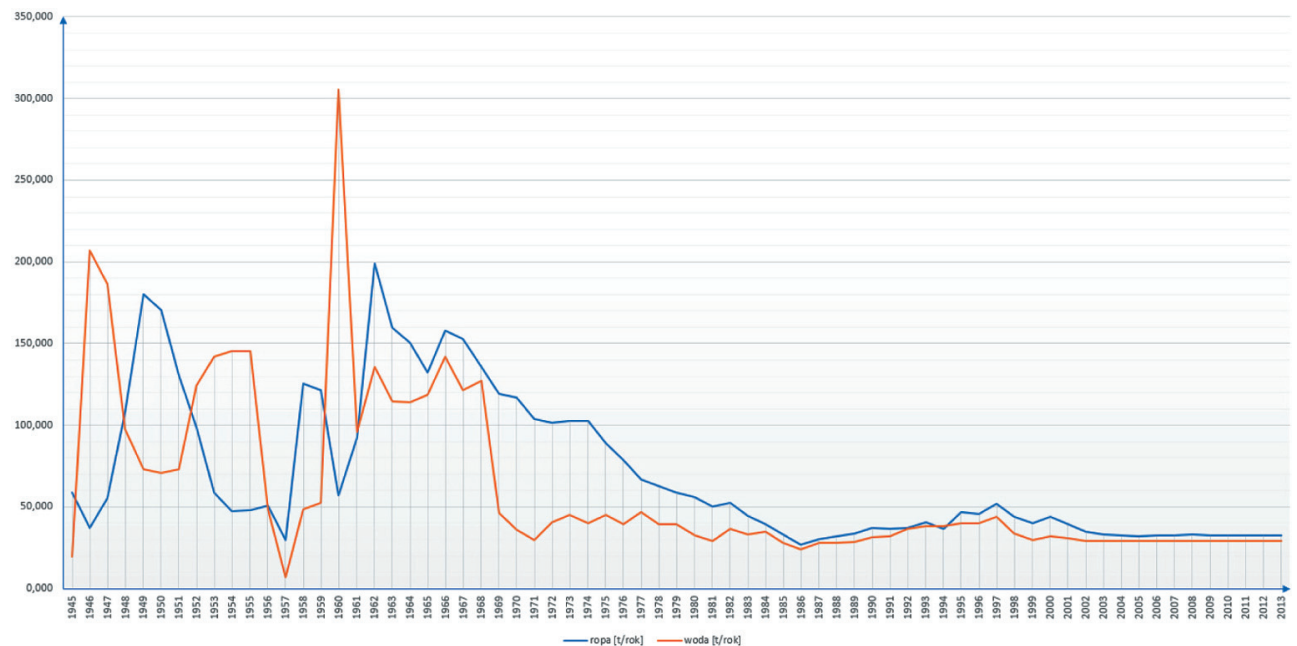

Rys. 5. Wykres przebiegu wydobycia ropy naftowej i wody ze złoża Potok

(II piaskowiec ciężkowicki - blok zachodni)

Źródło: opracowanie własne na podstawie Dokumentacja (2010)

\subsection{Analiza przebiegu eksploatacji ropy naftowej i wody na bloku wschodnim II piaskowca ciężkowickiego}

Na bloku wschodnim w okresie od 1945 do 1947 roku obserwuje się wzrost wydobycia ropy od wartości około $900 \mathrm{t}$ /rok do wartości około 1,35 tys. t/rok. Wartość ta stanowi maksimum w całym okresie eksploatacji. Od tego momentu następuje stopniowy spadek wydobycia ropy. Wraz z rozpoczęciem eksploatacji ropy obserwuje się bardzo duży wzrost wydobycia wody. W roku 1945 wydobycie wody wynosiło 6 tys. t/rok, a w roku 1947 - ponad 22 tys. t/rok. Oceniając ten okres przebiegu pracy złoża, należy stwierdzić, że eksploatacja - według obecnych kryteriów jej oceny ekonomicznej - była całkowicie nieopłacalna. Prowadzenie takiej eksploatacji było opłacalne prawdopodobnie dzięki możliwości utylizacji bardzo dużych ilości wody złożowej przy jednoczesnym dużym zapotrzebowaniu na ropę naftową po okresie II wojny światowej. Analizując dalszy przebieg eksploatacji ropy naftowej, należy stwierdzić, że odbywa się ona z łagodnym spadkiem, co świadczy zdaniem autorów o grawitacyjnym spływie ropy do odwiertów eksploatacyjnych. Wydobycie wody również spada, zbliżając się do wydobycia ropy. Eksploatowany gaz ziemny ma charakter tzw. gazu przynaftowego. Z uwagi na niepewność dotyczącą rejestracji danych o ilości wydobywanego gazu autorzy celowo zrezygnowali ze sporządzania wykresu przebiegu jego wydobycia w czasie. Ponieważ eksploatacja ropy naftowej na złożu Potok odbywa się metodą pompowania pompami wgłębnymi rurowymi typu R2, gaz towarzyszący ropie naftowej jest 
wykorzystywany jako gaz techniczny do przetłaczania ropy ze zbiorników przyodwiertowych do zbiorników magazynowych. $\mathrm{Z}$ dostępnej dokumentacji złoża ropy naftowej Potok wynika, że maksymalny zarejestrowany wydatek roczny gazu ziemnego wynosił 83 tys. $\mathrm{Nm}^{3}$ w roku 1946, a od roku 1965 ilość wydobywanego gazu nie jest rejestrowana. Obecnie na bloku wschodnim wydobycie ropy naftowej utrzymuje się na poziomie około 56 t/rok, a wydobycie wody - około 116 t/rok. Eksploatowana woda złożowa jest od roku 1994 zatłaczana do jednego z odwiertów położonych na bloku zachodnim.

\subsection{Analiza przebiegu eksploatacji ropy naftowej i wody na bloku środkowym II piaskowca ciężkowickiego}

W przebiegu eksploatacji bloku środkowego II piaskowca ciężkowickiego na rysunku 4 obserwuje się początkowo wzrost wydobycia ropy naftowej od wartości około 600 t/rok w roku 1945 do wartości 920 t/rok w roku 1950. Podobnie jak w przypadku bloku wschodniego również w odniesieniu do bloku zachodniego autorzy ze względu na wysoką niepewność rejestracji danych dotyczących wydobycia gazu nie sporządzili wykresu jego przebiegu. Wspomniany wzrost wydobycia ropy był wywołany prawdopodobnie dużym spadkiem ciśnienia. Jak podaje dokumentacja, w tym czasie obserwuje się duży wzrost rocznego wydobycia gazu ziemnego - do wartości 620 tys. $\mathrm{Nm}^{3}$ w roku 1956. Jednocześnie obserwuje się spadek wydobycia ropy. Po osiągnięciu maksimum wydobycie gazu spada. Zdaniem autorów w okresie od roku 1956 do roku 1991 eksploatacja ropy odbywa się dzięki energii gazu ziemnego. Od roku 1991 wydobycie gazu osiąga wartości śladowe i przestaje być ono raportowane, zaś eksploatacja ropy odbywa się głównie dzięki systemowi grawitacyjnemu. Potwierdzeniem dość intensywnej, żeby nie powiedzieć - rabunkowej eksploatacji złoża jest przebieg wydajności wody wydobywanej wraz $\mathrm{z}$ ropą. $\mathrm{Z}$ wykresu przebiegu eksploatacji wody na rysunku 4 wynika, że w okresie intensywnej eksploatacji ropy naftowej ilości wydobywanej wody były bardzo duże. Wykładniki wodne dochodziły do $9 \mathrm{t}$ wody na tonę wydobywanej ropy. Największa wartość rocznego wydobycia wody wynosi około 4,5 tys. t przy rocznym wydobyciu ropy około $500 \mathrm{t}$. W przypadku bloku środkowego podobnie jak w przypadku bloku wschodniego wydobycie wody jest duże, co świadczy o znacznym zawodnieniu się złoża w obu blokach.

\subsection{Analiza przebiegu eksploatacji ropy naftowej i wody na bloku zachodnim II piaskowca ciężkowickiego}

Eksploatacja ropy naftowej z bloków wschodniego i środkowego wydaje się zdaniem autorów mało efektywna, podyktowana głównie chęcią jej utrzymania. Najbardziej 
korzystny obraz przebiegu eksploatacji II piaskowca ciężkowickiego na złożu ropy naftowej Potok dotyczy bloku zachodniego. W przebiegu wydobycia ropy naftowej i wody na bloku zachodnim (rys. 5) widać zmiany sinusoidalne, przy czym w okresach, gdy wydobycie ropy rośnie, maleje wydobycie wody. Widać, że po okresie wzrostu wydobycia wody następuje z opóźnieniem wzrost wydobycia ropy. Maksymalną wartość, na poziomie 305 t/rok, wydobycie wody osiagga w roku 1960 przy minimalnym wydobyciu ropy, na poziomie około $60 \mathrm{t} /$ rok, zaś maksymalne wydobycie ropy, około $200 \mathrm{t} /$ rok, występuje w 1962 roku przy spadku wydobycia wody do wartości około 100 t/rok.

Po roku 1962 następuje spadek wydobycia ropy przy jednoczesnym spadku wydobycia wody. Od roku 1996 wydobycie obu płynów oscyluje blisko siebie. Od tego momentu zdaniem autorów uwidacznia się grawitacyjny system spływu tych płynów do odwiertów eksploatacyjnych. Patrząc na przebieg wydobycia ropy naftowej i wody w latach 2003-2013, obserwuje się prawie stałą eksploatację. Wstępne prognozy dalszej eksploatacji ropy z bloku zachodniego wskazują na długi okres jej trwania. Zakończenie eksploatacji ropy na tym bloku podyktowane może być tylko oceną ekonomiczną. Jak wiadomo, odwierty na tym złożu wykonywane były metodą udarową, która wydaje się mało ekonomiczna ze względu na czas wiercenia, ale jest wysoce korzystna ze względu na niewielki lub zerowy współczynnik skin effect. Niewielki skin effect w strefach przyodwiertowych zapewnia długotrwałą pracę odwiertów. Należy pamiętać, że wydajności tych odwiertów są niewielkie, rzędu kilkunastu - kilkudziesięciu kilogramów ropy na dobę. Dlatego, jak wspomniano wcześniej, o zakończeniu eksploatacji decyduje wyłącznie rachunek ekonomiczny.

\section{Podsumowanie}

Analiza przeprowadzona przez autorów dotyczyła przebiegu eksploatacji ropy naftowej na złożu Potok. Analiza była oparta na bardzo szczupłych danych, jakie są dostępne. Należy pamiętać, że złoże Potok zostało odkryte w 1890 roku i od tego czasu jest eksploatowane. Głównym horyzontem eksploatacyjnym analizowanym przez autorów był II piaskowiec ciężkowicki zalegający na głębokości od $260 \mathrm{~m}$ od powierzchni w części wschodniej do $700 \mathrm{~m}$ od powierzchni w części zachodniej. Przeanalizowany został przebieg eksploatacji ropy naftowej w okresie od 1945 do 2013 roku na trzech blokach: wschodnim, środkowym i zachodnim. Z przeprowadzonej analizy wynika, że bloki wschodni i środkowy są bardzo silnie zawodnione. Brak jest danych geofizycznych pozwalających na ocenę stopnia tego zawodnienia. Sugestia o zawodnieniu bloków wynika tylko z ilości wody dopływającej do odwiertów. Możliwe jest istnienie języków wodnych lub stożków wodnych. W ocenie autorów eksploatacja ropy naftowej 
na blokach wschodnim i środkowym jest możliwa przez 5-6 lat, zaś eksploatacja ropy naftowej na bloku zachodnim może być kontynuowana jeszcze przez co najmniej 10 lat. Kres tej eksploatacji może być podyktowany wyłącznie względami ekonomicznymi. Autorzy są w trakcie pogłębionej analizy eksploatacji bloku zachodniego. Wyrażają nadzieję, że wyniki prac będą zamieszczone w kolejnej publikacji.

\section{Literatura}

Biuletyn Instytutu Geologicznego, 1968, nr 215, t. 12, Wydawnictwa Geologiczne, Warszawa.

Dokumentacja geologiczna złoża ropy naftowej i gazu ziemnego Potok, 2010, Sanok. Karnkowski P., 1993, Złoża gazu ziemnego i ropy naftowej w Polsce. T. 2, Karpaty i zapadlisko przedkarpackie, Towarzystwo Geosynoptyków „Geos” AGH, Kraków.

Wdowiarz S., 1960, Ropa naftowa i gaz ziemny na tle geologii Karpat, Wydawnictwa Geologiczne, Warszawa. 